Fiscaoeconomia

E-ISSN: 2564-7504

2022, Volume 6, Issue 1, 20-39

https://dergipark.org.tr/tr/pub/fsecon
Research Article/Araştırma Makalesi

Submitted/Geliş: 29.12.2021

Accepted/Kabul: 19.01.2022

Doi: $10.25295 /$ fsecon.1050437

\title{
Amartya Sen: Kapasite Yaklaşımı ve Özgürlükle Kalkınma Sorunu
}

Amartya Sen: The Capacity Approach and the Problem of Freedom and Development

\section{Yavuz YAYLA ${ }^{1}$}

\section{Öz}

Her kriz döneminde artan ekonomik eşitsizlikler ekonomide hakkaniyetli bir bölüşümün nasıl olması gerektiği üzerine yapılan tartışmaların artmasına da neden olmaktadır. Bu amaçla da bu konuda düşünsel çaba harcayan düşünürlerin görüşleri tekrar ele alınmaktadır. Bu düşünürlerden birisi de önemli bir iktisat felsefecisi ve/ya sosyoloğu olan Amartya Sen'dir. Biz bu çalışmada Amartya Sen'in geliştirdiği kapasite yaklaşımı ile özgürlükle kalkınma arasındaki ilişkiyi nasıl ele aldığını irdeleyeceğiz.

Jel Kodları: P16, B41, D63.

Anahtar Kelimeler: Politik iktisat, Ekonomik Metodoloji, Amartya Sen, Eşitlik, Adalet, Eşitsizlik.

\begin{abstract}
Increasing economic inequalities in each crisis period also causes an increase in the discussions on how a fair distribution in the economy should be. For this purpose, the views of thinkers who have made intellectual efforts on this subject are discussed again. One of these thinkers is Amartya Sen, an important economic philosopher and/or sociologist. In this study, we will examine the capacity approach developed by Amartya Sen and how he deals with the relationship between freedom and development.
\end{abstract}

Jel Codes: P16, B41, D63.

Keywords: Political Economy, Economic Methodology, Amartya Sen, Equity, Juctice, Inequality.

\footnotetext{
${ }^{1}$ Dr., Ondokuz Mayıs Üniversitesi, İiBF, iktisat Bölümü, yavuzyayla@gmail.com, ORCID:0000-0002-8720-801X
}

Citation/Atıf: Yayla, Y. (2022). Amartya Sen: Kapasite Yaklaşımı ve Özgürlükle Kalkınma Sorunu. Fiscaoeconomia, 6(1), 20-39. Doi: 10.25295/fsecon.1050437 
Yayla, Y. (2022). Amartya Sen: Kapasite Yaklaşımı ve Özgürlükle Kalkınma Sorunu.

Fiscaoeconomia, 6(1), 20-39. Doi: 10.25295/fsecon.1050437

\section{Giriş}

Amartya Sen, bölüşüm adaletinin belirlenmesinde insanların bireysel olarak sahip oldukları kapasitelerinin çeşitliliğine öncelik tanımaktadır. Sen, John Rawls'ın adalet teorisini ve diğer adalet teorilerini de bu çerçevede eleştirmektedir. Sen'e göre, adalet teorisi, bir kişinin temel kapasiteleri çerçevesinde ele alınmalıdır. Düşünür, bu temel bağlamda yer alan 'temel kapasite' kavramını 'neyin eşitliği?' sorusunu ele alırken geliştirmiş ve kapasite teorisini öncelikle Rawls'ın hakkaniyet olarak adalet teorisinin güçlü yanlarını ve eksikliklerini değerlendirerek ortaya koymuştur (Gilardone, 2015:22).

Sen, ekonomik ve normatif yönden 'eşitlik' kavramını, "bireysel avantajı, elde etme özgürlüğüne ve bu özgürlüğü ileriye taşımak üzere gerçek başarıları birleştirme” şeklinde değerlendirilmesi gerektiğini ifade etmektedir. Sen'e (1992:129) göre eşitlik kavramı ile ilişkili olarak ortaya çıkan bireysel refahın değerlendirilmesinde “...bir kişinin fiilen ulaşabileceği en üst düzey işlevler ve bu işlevleri aşarak yeni işlevler görme yeteneği" dikkate alınmalıdır. Bu bağlamda kapasite yaklaşımı (capability approach), genel olarak elde etme özgürlüğünü ve özellikle işlevsel kapasiteleri inceleme gerekliliğini zorunlu kılmaktadır.

\section{John Rawls'da Adaletin IIlkeleri ve Sen'in Eleştirisi}

Sen, kapasite yaklaşımını Rawıs'un birincil mallar yaklaşımı ile karşılaştııır ve Rawls'ın gereksinmeleri elde etme özgürlüğündeki eşitsizliklerin özgürlük lehine feda edildiğine dikkat çeker. Çünkü eşit birincil mal demetleri olan iki birey, insan çeşitliliği nedeniyle, amaçları aynı olsa bile, amaçlarına ulaşmak için çok farklı özgürlüklere ve fırsatlara sahip olabilirler (Sen, 2004:90). Sen, Rawıs'ın birincil mallar eşitliği yaklaşımının, sınıf, cinsiyet, yer veya genetik koşullardan kaynaklanan eşitsizliklerle yeteri kadar başa çıkamayacağını savunmaktadır (Sen, 2004:92). Bununla birlikte, kanaatimizce, Sen açıkça veya dolaylı olarak Rawls'ın adalet teorisini kendi teorisini geliştirirken çıkış noktası olarak kullanmıştır.

Rawls adalet teorisinde iki ilkeye yer vermektedir: "ilk ilke: Her kişi, herkes için benzer bir eşitlik sistemiyle uyumlu olan bütün bir eşit temel özgürlükler sisteminde yer almak için eşit haklara sahiptir. İkinci ilke: Sosyal ve ekonomik eşitsizlikler öyle düzenlenmelidir ki, (a) bu eşitsizlikler, adil tasarruf ilkesine uygun olarak en az avantajlı olanın en büyük faydasına olmalıdır ve (b) adil fırsat eşitliği koşulları altında makamlar ve mevkiler herkese açık bulunmalıdır." (Rawls, 2005:302)

Rawıs'ın özgürlük ilkesi olarak nitelendirilen ilk ilkesi vatandaşların haklarını kullanmaları ve yükümlülüklerini yerine getirmeleriyle ilgili olup, bu ilke, temel özgürlükleri tanımlamakta ve güvence altına almaktadır. İlk ilkeye göre, herkes, adil bir toplumda temel özgürlükleri kullanabilir ve temel özgürlüklerde hak sahipliği bakımından herkes eşit haklara sahiptir. Rawls'ın adalet ilkesinin ikinci kısmını ise eşitlik ilkesi oluşturur. Bu ikinci ilke de kendi içerisinde adil fırsat eşitliği (fair equality of opportunity) ilkesi ve fark ilkesi (difference principle) olarak ikiye ayrılır. Eşitlik ilkesi altındaki iki ilkeden ilki olan adil fırsat eşitliği ilkesi, fırsat eşitliği koşulları altında makam ve mevkilerin herkese açık olmasını ve bu çerçevede din, dil, ırk, mezhep, cinsiyet vb. önem arz etmeksizin herkesin belli bir makam veya mevkiye gelebilmek bakımından eşit olmasını ifade eder. Eşitlik ilkesi altındaki iki ilkeden ikincisini oluşturan fark ilkesi ise, esas itibariyle sosyal ve ekonomik eşitsizliklerin düzenlenmesine, başka bir ifadeyle sosyal ve ekonomik eşitsizliklerin dağılımına ilişkin bir husus olup, bu tür düzenlemelerin 
Yayla, Y. (2022). Amartya Sen: Kapasite Yaklaşımı ve Özgürlükle Kalkınma Sorunu.

Fiscaoeconomia, 6(1), 20-39. Doi: 10.25295/fsecon.1050437

toplumun en az avantajlı kesimine yarar sağlayacak nitelikte olması gereğini içerir. Rawls'a göre, bu ilkeler arasında dizinsel bir öncelik (lexical priority) ${ }^{2}$ vardır ve bu çerçevede özgürlük ilkesi, eşitlik ilkesinden; eşitlik ilkesi içinde de adil fırsat eşitliği ilkesi fark ilkesinden önce gelir.

Rawls'a göre, birinci ilke olan özgürlük ilkesi, ikinci ilke olan eşitlik ilkesine ve özellikle de fark ilkesine göre daha öncelikli yerde bulunması bir zorunluluktur; çünkü ancak kurulan bu öncelik aracılığıyla, "birinci ilkenin kapsamındaki temel haklar ve özgürlükler ile fark ilkesiyle düzenlenen toplumsal ve ekonomik avantajlar arasındaki değiş tokuş ilişkilerine (iktisatçıların kullandığı ifadeyle 'mübadele'lere) engel olunabilir. Örneğin, eşit siyasal özgürlükler, bir grubun bu siyasal özgürlüklere sahip olması onların ekonomik büyüme ve verimlilik için ihtiyaç duyulan politikaları engellemelerine imkân vereceği gerekçesiyle çiğnenemez." (Rawls, 2020b:76). Bu şekilde Rawls, "özgürlüğün önceliğine” önem vermekte ve özgürlüklerin diğer tüm birincil mallar üzerindeki haklara göre daha dokunulmaz bir değere sahip olması gerektiğini belirtmektedir. Bu çerçevede, ilk adalet ilkesi, ikinci adalet ilkesi ve özellikle de fark ilkesine başvurulmadan önce yerine getirilmelidir (Rawls, 2019:51). Bu nedenle, tüm insanlar temel siyasi ve sivil özgürlüklerde eşit paya sahip olmalıdır. Ancak bu temel özgürlükler dışındaki birincil mallara ilişkin haklar örneğin, gelir ve servet edinme hakkı, özgürlük hakkından üstün tutulamaz. Örneğin, gelir ve servet dağılımındaki eşitsizlikte en az avantajlı olanın "daha fazla yararı" olduğu sürece, bu eşitsizliğin giderilmesine gerek yoktur.

Sen, Rawls tarafından özgürlük ilkesi ve diğer avantajlar arasında kurulan dizinsel önceliğe eleştirel bir şekilde yaklaşmakta ve özgürlükler ile diğer avantajlar arasında kurulan bu tür bir öncelik ilişkisinde, nasıl olup da ölüm kalım meselesi olabilen bir ekonomik ihtiyacın, kişisel özgürlükten daha aşağı bir statüde sayılabileceği sorusunu sormaktadır (Sen, 2004:91). Bu çerçevede Sen, bu tür bir önceliğin bulunup bulunmadığının değil, “...bir kişinin özgürlüğünün, diğer kişisel avantaj tipleriyle -gelirler, faydalar vb.- aynı derecede önemli (daha fazla değil) olup olmadığı"nın tartışılması gerektiğini savunmaktadır (Sen, 2004:91).

Sen'e göre, “...Rawls'ın adalet teorisinin çözümlenmesinde birincil değerler belirleyici bir çeşitlilik içinde ("haklar, özgürlükler ve fırsatlar, gelirin ve servetin ve özsaygının temeli olarak") görülür ve Rawls bunları eldeki birincil değerlere ilişkin kapsamlı bir 'endeks'le ele alır." (Sen, 2004:113). Sen, bu yaklaşımı, fiziki olarak özürlü bir insanın fayda dezavantajı ve bu eşitlik ölçüsünün, bu çerçevede, fark ilkesinin uygulanmasında birincil değerlerin önceliğinin temel kıstas olması nedeniyle insan çeşitliliğini hesaba katmadığı gerçeğini gerekçe göstererek eleştirmektedir.

Hükümetlerin, politika yapıcılarının ve ilgili üçüncü kişilerin, insanların refahını kendi iradeleri dışında takip edecekleri veya teşvik edecekleri, diktatörce veya ataerkil bir yaklaşımı savunmayan ve buna razı olmayan (Alexander, 2016:9) Sen, aslında bir dereceye kadar Rawls'ı siyasi ve sivil özgürlüklere öncelik vermesi nedeniyle klasik bir liberal olarak kabul etmektedir (Sen, 2004:90-92). Çünkü Sen, Rawls'ın temel siyasi ve sivil hakları içeren özgürlüğün diğer haklara nazaran üstün olduğu iddiasını eleştirmekte ve özgürlüğü sadece kişinin -fazladan bir gelir birimi gibi- bizzat elde ettiği bir avantaj olarak değerlendirmenin yeterli olmadığını ve bu nedenle de birincil değerler kavramının yetersiz bir teori olduğunu ileri sürmektedir (Sen,

\footnotetext{
${ }^{2}$ Bu husus, Rawls'ın eserlerinden yapılan Türkçe çeviriler ile Rawls'a ilişkin çalışmalarda genellikle "sözcüksel öncelik" olarak dilimize çevrilmektedir. (Yazarın Notu)
} 
Yayla, Y. (2022). Amartya Sen: Kapasite Yaklaşımı ve Özgürlükle Kalkınma Sorunu.

Fiscaoeconomia, 6(1), 20-39. Doi: 10.25295/fsecon.1050437

2004:91). Nuno Martins'e (2007:39) göre de Sen, Rawls'ın (servet, gelir, haklar, özgürlükler, fırsatlar ve özsaygının sosyal temellerini içeren) 'birincil malların' refah ve avantajı değerlendirmek için uygun alan olduğu görüşünü eleştirdiğini belirtir.

Sen, Rawls'un özgürlük fikrini kusurlu bulur. Sen'e göre, Rawls'ın yaptığı gibi birincil değerlere öncelik atfetmek kısmen kör bir ahlâka yol açar (Sen, 1979:216). Sen, Rawls'ın birincil değerlere ilişkin eşitlik yaklaşımını da "fetişist" (fetishist) olarak nitelendirmektedir. Rawıs'ın, birincil değerleri (özgürlükleri), mallar ve insanlar arasında bir ilişki olmaktan çok, menfaatin somutlaşmış hali olarak ele alması (Sen, 1979:216) ve bu şekilde birincil değerleri, kişiler ve mallar arasında bir ilişki olarak kullanmak yerine, avantajın somutlaşması olarak düşünmesi, Sen'e göre, Marx'ın 'meta fetişizmi' olarak adlandırdığı tanımlamanın tuzağına düşmektir (Sen, 1979:216). Çünkü meta sahipliği, refaha (well-being) ulaşmanın bir aracıdır, ancak kendinde bir amaç değildir. Birincil değerleri, kendilerine, (ve bir ölçüde) kişilere yardım etmek için değil, doğrudan kavramın kendisi olarak değerli kabul etmek fetişizme yol açar (Sen, 1999:19). Fakat Sen'e göre, faydacılık ya da daha genel olarak refahçılık bu fetişizme sahip değildir, çünkü kamu hizmetleri insanlar ve mallar arasındaki bir tür ilişkinin yansımalarıdır. Örneğin, gelir ve zenginlik, faydacılık altında fiziksel birimler olarak değil, insan mutluluğunu yaratma veya insan arzularını tatmin etme kapasiteleri açısından değerlendirilir. Fayda, bir kişi için doğru odak noktası olarak görülmese bile, iyi bir ilişki, tamamen iyi yönlendirilmiş bir çerçeveye sahip olmak, avantajı değerlendirmek için kendine özgü bir yol sağlar (Sen, 1979:216). Bununla birlikte gelir ve kaynaklar kişinin refahı için sadece bir araçtır. Sen'e göre, önemli olan ve ölçülmesi gereken insanların bu kaynaklarla ne yapabildiğidir. Gelire odaklanan refah iktisadındaki eşitsizlik çalışmaları, insanların neyi yapabileceği veya ne olabileceğini göstermediğinden ve bunun yerine insanların tükettiği mallara ve gelirlerine odaklanması Sen tarafından eleştirilmektedir (Sen, 1979:216).

Birincil değerlerin fetiş haline getirildiğini vurgulayan Sen'e göre, normatif değerlendirmenin temelleri; ne özgürlük araçları (birincil değerler, kaynaklar veya gelirler gibi) ne de zihinsel durumlar (mutluluk ve tatmin gibi) olmalıdır. En uygun bakış açısı, kapasiteler ve işlevselliklerdir (Sen, 1979:216). Başka bir ifadeyle, Sen, Rawls'un birincil mallar kavramının kapsamlı bir iyilik anlayışı içerdiğini veya varsaydığını reddetmektedir. Birincil mallar özgürlügün kurucu unsurunu oluşturmazlar, daha ziyade özgürlük için bir araç olarak veya "maddi eşitlik fırsatını" elde etmek için bir araç olarak görülmelidir. Diğer bir ifadeyle, araçlar sadece bireylerin elde etmesini istedikleri amaçlara göre değerlendirilebildiğinden, araçları amaçlarını göz önüne almadan değerlendirmek gerçekten mümkün değildir. Bu nedenle, Sen'in teorisinin merkezinde etkinlikler ve fırsatlar olarak tanımlanan "işlevler" ve "kapasite" kavramları vardır. Ayrıca Sen, insanoğlunun "temel işlevlerini" sürdürebilmesinin adalet için asgari şart olması gerektiğinde ısrar etmektedir.

Sen'e göre, bir eşitlik teorisi Rawls'un birincil mallar yaklaşımı ile refahçı eşitlik kavramlarını birleştirmeli, yani bireysel ihtiyaçların karşılanması memnuniyet düzeylerini yansıtmalıdır. Çünkü Sen'e göre, “Faydacılar, genel olarak, farklı insanlar tarafından kullanılan toplam kamu hizmetlerinin eşitliğini istemezler. Faydacı formülde, tüm insanların faydalarının toplamının maksimuma çıkarılması önemlidir ve açık bir şekilde, özellikle eşitlikçi değildir. Aslında, faydacılığın aradığı eşitlik, insanlara kamu hizmeti kazançları ve kayıpları alanında eşit muamele biçimini alır. Faydacı nesnel işlevde herkesin fayda kazancında eşit ağırlıkta ısrar 
Yayla, Y. (2022). Amartya Sen: Kapasite Yaklaşımı ve Özgürlükle Kalkınma Sorunu.

Fiscaoeconomia, 6(1), 20-39. Doi: 10.25295/fsecon.1050437

vardır." (Sen, 2009:1) Kısaca faydacılık, belirli malların mülkiyetine sahip olmak ya da bunları kontrol etmeye yoğunlaşırken, Rawls, kişinin mal stoklarını ihtiyaç tatminine veya mutluluğa dönüştürmeye gerek duymadan sadece malların varlığına odaklanır.

Sen'e göre, temel kapasitelere odaklanma, Rawls'un birincil mallara bakışının doğal bir uzantısı olarak görülebilirse de dikkati mallardan, malların insanlara ne yaptığına kaydırır. "Temel kapasitenin bu yaklaşımına karşın Rawıs'ın yaklaşımı örneğin gelirin ne yaptığından çok gelir üzerine, 'özsaygının toplumsal temelleri' yerine özsaygının kendisine odaklanır.” (Sen, 2009:5).

Göreceli önem taşıyan düşüncelerin toplumun doğasına bağlı olduğunu vurgulayan Sen'e göre "Temel kapasitelerin eşitliği kavramı çok geneldir, ancak bunun herhangi bir uygulaması, özellikle farklı kapasitelerin ağırlıklandırılmasında kültüre bağımlıdır." Hindistanlı bir liberal olan Sen'e göre, Batı modernizminin bir sonucu olarak, Rawls'ın eşitliğe yaklaşımı hem kültüre bağımlı hem de fetişist bir özelliğe sahip iken, temel kapasite eşitliği fetişizmden kaçınırken, kültüre bağımlı bir özellik sergiler (Sen, 2009:5; Quinn, 2019:132). Bununla birlikte Sen, aslında, temel kapasite eşitliğinin, Rawls'ın yaklaşımının fetişist olmayan bir uzantısı olarak görülebileceğini belirtir (Sen, 1979:219). Nuno Martins'in ifadesiyle, Sen, kapasite yaklaşımının orijinal formülasyonunda Rawls'ın birincil mallara olan vurgusunu eleştirse de, Rawls'ın teorisini tamamen değil sadece bir kısmının değiştirilmesini savunmaktadır (Martins, 2007:41).

Farklılık prensibini eleştiren Sen'e göre, Rawls'ın temsili bireyleri temelde çok benzer olsaydı, birincil mallar endeksi avantajı değerlendirmek için oldukça iyi bir yöntem olabilirdi. Ancak, gerçekte, insanların sağlık, uzun ömür, iklim koşulları, yer, çalışma koşulları, mizaç ve hatta (yiyecek ve kıyafet gereksinimlerini etkileyen) vücut büyüklüğüne göre çok farklı ihtiyaçları olduğu görülmektedir. Dolayısıyla, işin içinde olan sadece birkaç zor olan olayı görmezden gelmek değil, aynı zamanda çok yaygın ve gerçek çeşitliliklere bakmaktır (Sen, 1979:215-216). Başka bir deyişle, Sen'e göre, bir eşitlik değerlendirmesi faaliyetine girişilmek isteniyorsa başlangıç noktası çeşitlilik varsayımı olmalıdır.

Sen'e göre, çeşitlilik varsayımının göz önüne alınması sayesinde, insanların tercih ettikleri bir yaşam biçimini seçerken birincil malları nasıl dönüştürebilecekleri veya etkili şekilde kullanabilecekleri konusunda büyük çeşitliliği görmek mümkün olmaktadır. Sen, birincil malların eşitliğinin pratik yaşamda ciddi eşitsizliklerle birlikte var olabileceğini ve bu durumun örtbas edebileceğini savunmuştur. Örneğin, ona göre, engelli bir kişi daha fazla birincil mallara sahip olabilir, örneğin daha fazla gelir sahibi olabilir ancak daha az gelire sahip olanlara göre istediği türde bir hayat sürdürme olasılığı daha az olabilir. Üstelik yoksulluğun pratik yaşamda görünümü çoğunlukla tek başına bir miktar birincil mal tarafından aktarılamaz. Bu bağlamda, birincil malların amaçlar adına gerçek seçimlere dönüştürülmesi için insan çeşitliliğine örneğin yaş, sakatlık ve hastalık eğilimi gibi özelliklere de dikkat etmek gerekmektedir (Sen, 1992:81). Bir başka ifadeyle, insanların çeşitliliğini düşündüğümüzde insanların amaçlarının birbirinden farklı olduğunu ve bu nedenle ihtiyaçlarının da farklılık gösterdiğine dikkat edilmelidir. Dolayısıyla, aynı amaçlara ulaşmak için, daha dezavantajlı durumda bulunan örneğin fiziksel olarak engelli bir kişinin, sağlıklı bir bireye göre farklı kaynaklara ihtiyacı bulunmaktadır. Bu nedenle, eşitliği belirlemek için, ister özgürlüğün birincil iyiliği ister başka bir şey nedeniyle yalnızca birincil mallara odaklanmak yeterli değildir. Aksine, Sen, eşitliğin sadece mallar ve kişiler arasındaki ilişki açısından belirlenebileceğini söylemektedir (Sen, 1979:216; Sen, 1990:115). 
Yayla, Y. (2022). Amartya Sen: Kapasite Yaklaşımı ve Özgürlükle Kalkınma Sorunu.

Fiscaoeconomia, 6(1), 20-39. Doi: 10.25295/fsecon.1050437

Rawıs'a göre farklı kişilerin göreceli durumlarının kendileri için mevcut olan kaynak paylarını karşılaştırarak en uygun kararı alabilecekleri iddiası kusurludur. Rawls'ın bu iddiasına karşıt olarak Sen, insanların kendi amaçlarına ulaşma yeteneklerinde değişikliklere neden olan iki kaynağı tanımlar (Sen, 1992:85): (a) insanların mallarla ilgili farklı anlayışlarına sahip olduğu fikri ile eşitlenebilen uçlar-arası varyasyonlar ve (b) bireyler-arası varyasyonlar, yani benzer mal demetleri göz önüne alındığında, insanların ihtiyaçları ve amaçlarına ulaşma kapasitelerinin veya kapasitelerinin çeşitliliği. Sen'e göre, Rawls'un birincil mallar teorisi, çoğulcu politik anlayışının bir gereği olarak uçlar-arası varyasyona hassasiyet göstermektedir ama bireyler-arası varyasyonu hesaba katmamaktadır. Bu bağlamda "Uçlar-arası varyasyonlarla" ilgili olan Rawls'ın adalet anlayışında, birincil mallar, bir mal teorisine indirgenemeyen çeşitli amaçların peşine düşmek için ortak araçsal indeks sağlamaktadır. Ancak, Sen'e göre, Rawıs'un adalet teorisi amaçlarını gerçekleştirmek için bu malları kullanan insanları ifade eden "bireyler-arası varyasyonlarla" ilgilenmemektedir. Bu durumda eşitlik, sadece tek bir kişinin özgürlügü̈yle ilgili olamaz ve kişinin amacını gerçekleştirmeye çalışırken engellerin olmaması olarak anlaşılmalıdır (Sen, 1992:85).

Daha önce de ifade ettiğimiz üzere Rawls, birincil malları ikincil mallara üstün tutmaktadır. Çünkü Rawls'a göre "Yoksulluk ve cehaletin bir sonucu olarak birisinin haklarından ve fırsatlarından yararlanamaması genel olarak bir araç eksikliği, bazen de özgürlüğü belirleyen kısıtlamalar arasında sayılır. Ancak bunu söylememeliyim, fakat daha çok bunların özgürlüğün değerini yani ilk ilkenin tanımladığı hakların bireylerine verdiği değeri etkilediğini düşünüyorum." (Rawls, 2005:204). Bu çerçevede Daniels'in vurguladığı gibi, Rawls, ekonomik faktörleri ve belki de ideoloji gibi diğer faktörleri özgürlüğü tanımlayan kısıtlamalar arasından açıkça dışlamaktadır. Daniels'e göre, Rawls için özgürlüğün değeri, 'daha büyük otorite ve servet" sahipleri için daha yüksektir ve onların amacı 'daha çok araç elde etmektir'. Bu nedenle de Rawls, sadece yoksulluğu reddetmekle kalmamış, ekonomik faktörler özgürlüğü tanımlayan kısıtlamalar kategorisinin dışında tutulmuştur (Daniels, 1989:260). Fakat Sen'e göre “iktisadi özgürlügün olmamasının cezası" ölümdür (Sen, 2004:23). Bu nedenle iktisadi özgürlüğün olmamasının sonucu Rawls'ın adaletin birinci ilkesinin sakatlanması anlamına gelir. Sen'e göre, Rawls'un ahlaki ve politik felsefesinde özgürlükte eşitliğin rolü, faydacılığın eşitlikçi varsayımları kusurlu olsa da belirleyici bir gelişmeyi temsil eder. En azından, Rawls ilk adalet ilkesinde, bakış açısının temeline eşit özgürlükler koymaktadır. Rawls, Siyasal Liberalizm kitabında adaletin birinci ilkesini şu şekilde tanımlamaktadır: "Herkes başkalarının özgürlükleriyle uyumlu tamamen yeterli eşit temel özgürlükler düzenine sahip olma yolunda eşit hakka sahiptir." (Rawls, 2019:320).

Öte yandan faydacılık, bir fayda ölçüsünün birincil iddialarının arkasındaki ikincil statüye seçme hakkı verir. Böylece Sen, Rawıs'un eşitlik tartışmasını daha verimli bir yöne, bir fayda "sonucundan" özgürlük için bir "fırsata” dönüştürdüğünü savunmaktadır. Ancak Sen'e göre, Rawls kendi felsefesinin merkezine eşit özgürlükleri koymasına rağmen, özgürlüğü en iyi şekilde bir araç olarak görmektedir. Oysa özgürlük kendi başına bir amaç olarak ele alınırsa eşitlikçi adalet için en iyi temel sağlanmış olur.

Sen'in, Rawls'ın eşitlikçi kavramlarına yönelik bir eleştirisi de ikincil malların eylem aracı olarak kullanılmasına yöneliktir. Çünkü Rawls'a göre, "birincil mallar rasyonel bir kişinin her ne olursa olsun istediği bir şey olarak varsayılan şeylerdir. Bir bireyin rasyonel planlarının ayrıntıları 
Yayla, Y. (2022). Amartya Sen: Kapasite Yaklaşımı ve Özgürlükle Kalkınma Sorunu.

Fiscaoeconomia, 6(1), 20-39. Doi: 10.25295/fsecon.1050437

dikkate alındığında, o bireyin değişik şeyler içinden az olanı değil, çok olanı tercih edeceği varsayılır. Bu malların çoğuyla, insanlar, amaçlarını gerçekleştirmede ve ilerletmede genellikle daha büyük başarı elde edebilirler. Bu mallar haklar ve özgürlükler, fırsatlar ve güçler, gelir ve servettir." (Rawls, 2005:92).

Bu bağlamda Sen'e göre, dağıtıcı bir eşitlik, hem sınırsız amaçların peşinden gitme hem de bu arayışı duygusal, fiziksel, politik, vs. gerçekleştirme gücü ile mümkün olmaktadır.

\section{Sen'in Kapasite Eşitliği Teorisi ve İşlevler}

Sen, ilk çalışmalarında kapasite yaklaşımını açıklarken bu kavramın Adam Smith ve Karı Marx tarafından kullanılan bazı kavramlarla ilişkili olduğunu düşündüğünü ama en güçlü kavramsal bağlantıların Aristoteles'in insani iyiliğe (gelişime) (eudaimonia) bakışı ile belirlenebileceğini belirtir (Sen, 1993:46). Sen'e göre, “Aristoteles'in insan iyiliğine ilişkin açıklaması, açıkça 'ilk olarak insanın işlevini tespit etme' gerekliliği ile bağlantılıdır ve daha sonra 'eylem anlamında hayatı' keşfetmeye devam eder. İşlevsellik yeteneğinin adil dağılımın temeli Aristoteles'in politik dağıtım teorisinde merkezi bir konumda bulunmaktadır. Bir kişinin işlev ve kapasitelerinin hayati öneminin kabul edilmesi, özellikle dağıtım düzenlemelerinin politik bağlamında yeterince açık bir şekilde ortaya çıkmaktadır." (Sen, 1993:46).

Sen “Neyin Eşitliği?” isimli çalışmasında; faydacılığın ve Ralws'ın adalet düşüncesinin eşitliğe olan yaklaşımlarını eleştirerek, "kapasite" kavramını geliştirmiştir. Kapasite yaklaşımı, normatif değerlendirmelerde refahçı (faydacılık) ve kaynak temelli (örneğin Dworkin) yaklaşımların aksine, insanların gerçekten ne yapabilecekleri veya ne olabilecekleri üzerine yoğunlaşan bir yaklaşımdır. Kapasite yaklaşımının temel iddiası; bir kişinin ne kadar iyi bir durumda olduğunu anlamak için, kişinin ne tarz bir yaşam sürdüğü, varoluş (beings) ve eylemler (doings) konusunda neleri başardığına bakmak gerektiği şeklindedir. Dolayısıyla, kapasite yaklaşımı, bireysel refah ve toplumsal düzenlemelerin değerlendirilmesi, toplumdaki değişimlere yönelik önerilerin ve politikaların tasarımı için geniş bir normatif çerçeve olarak tanımlanabilir.

Bir başka ifadeyle, Sen'in kapasite yaklaşımı, sadece özgürlük ${ }^{3}$ yollarına sahip olmaktan çok amaçlara ulaşma özgürlüğünün kapsamına odaklanmaktadır. Bu bağlamda da bir kişinin herhangi bir zamanda başardığı işlevler (örneğin Çince öğrenmek, iyi bir gurme olabilmek, yüzebilmek, birini sevebilmek vb.), belirli varoluş, eylemler veya hoşlandığı şeylerdir. Nicholas Garnham'ın belirttiği gibi, kapasiteler yaklaşımı, soruna çok daha ince bir yaklaşım ile bakmamıza ve ilgili konunun (örneğin medyanın) farklı potansiyel kullanımları ile fiilen yapılan kullanımlar arasında ayrım yapmamıza ve mevcut potansiyellerin neden hayata geçirilmediğini sormamıza olanak tanımaktadır (Garnham, 1997:32).

Michael Quinn'in ifadesiyle, kapasiteler ve işlevler, 'refah' ve 'kaynaklar'ın güçlü yönlerini yakalamak ve zayıflıklarından kaçınmak amacıyla merkezi değişkenler olarak ele alınmıştır (Quinn, 2019:120). Bir insanın özgürlüğünün kapsamı, onun kullanabileceği kaynaklar, ihtiyaçları, fiziksel ve zihinsel yetenekleri göz önüne alındığında, Sen tarafından bireyin elde edebileceği "işlevler" olarak tanımladığı "kapasite seti"nin (Sen, 1992:33-34) bir

\footnotetext{
${ }^{3}$ Hülya Kirmanoğlu'nun da belirttiği üzere "Sen için özgürlük, bir çok liberal iktisatçı için olduğundan farklı bir anlam taşımaktadır. Özgürlükler sadece seçme ve seçilme hakkı gibi formel özgürlükleri değil, fakat eğitim ve sağlık hakkı gibi reel özgürlükler de kapsar." (Kirmanoğlu, 2005:25).
} 
Yayla, Y. (2022). Amartya Sen: Kapasite Yaklaşımı ve Özgürlükle Kalkınma Sorunu.

Fiscaoeconomia, 6(1), 20-39. Doi: 10.25295/fsecon.1050437

fonksiyonudur. Sağlıklı olmak, mutlu olmak, özsaygıya sahip olmak ve benzeri her şey (Sen, 1992:39) "işlevler" veya "bir kişinin emrindeki mallar ve bireysel özellikler ile başarılı bir şekilde yaptığı şey”lerdir (Sen, 1999:6-7). İşlevler, bir kişinin bir şeye değer vermesinin nedeni olduğu durumları ifade etmektedir. $O$ halde bireyin özgürlüğünün kapsamı, kapasite kümesinin büyüklüğü, yani başarabilecek konumda olduğu işlevler kümesidir.

İnsanların kendiliğinden önemli kabul ettikleri kaynaklar, faaliyetler ve tutumlar için bir çerçeve kavram olan işlevler Sen'e göre, aynı zamanda bireylerin refahını da yansıtmaktadır: "Bir kişinin ne kadar iyi olduğunun, ne tür bir hayat yaşadığının ve kişinin 'yaptığı' veya 'neyi' başardığına ilişkin" gerçeği gösterdiği ölçüde refahı yansıtmaktadır." (Sen, 1999:19). Sen ayrıca, işlevlerin bir kişinin varlığını oluşturan unsurlar olduğunu ve bunların hem eylemlerinin hem de bir kişinin varoluş durumlarının özellikleri olduğunu belirtir (Sen, 1999:6-11). Bu bağlamda işlevler, "yeterince beslenme ve önlenebilir hastalıklara yakalanmama gibi temel işlevlerden, topluluk hayatına katılabilme ve özsaygı duygusuna sahip olma gibi çok karmaşık etkinliklere veya kişisel durumlara" (Sen, 2004:107) kadar uzanır.

Sen'e göre, kaynakların önemi ise türevseldir. Sen'e göre, "Birincil malların veya kaynakların türevsel önemi, birincil malları veya kaynakları ilgili hedeflerin gerçekleştirilmesine veya bunları takip etme özgürlüğüne dönüştürmek için ilgili fırsatlara bağlıdır." (Sen, 1992:19). Bu nedenle, işlevsellikler, amaçlara göre değerlendirilip, bir bireyin kapasite kümesinin büyüklüğü veya özgürlüğünün kapsamı, işlevlerin göreli değerlerinin bütünlüğü tarafından belirlenir. Sen'in bireylerinin işlevlere değer vermesinin nedeni onları hedef başarılarına dönüştürebilme kapasitesinde olmasındandır.

Sen'e göre, bir bireyin toplumdaki konumu iki farklı yönden ele alınabilir. Birincisi bireyin eylediği gerçek başarılarıdır. İkincisi ise amaçlarına ulaşmak için gerçek fırsatlar örneğin gelir veya serveti ile yani yaşam standardı aracılığıyla elde etme yani başarabilme özgürlüğüdür. Arzulanan bir toplumsal düzenlemenin inşa edilmesine yönelik bazı teorik ve pratik yaklaşımlar, gerçek başarıların ve elde etme özgürlüğünün farklı kavramlarını bir araya getirmektedir. Örneğin, fiili faydaya dayalı olarak bireyler arası karşılaştırmalar yapan, yalnızca elde etme değerine ulaşma özgürlüğünü ele alan faydacılık gibi.

Faydacılık fiili başarılara önem verirken, Rawls'un "birincil malları" veya Dworkin'in "kaynakları" gibi teorik düzenlemeler başarı araçlarına değer atfetmektedirler. Bu iki farklı duruş noktasına karşıt olarak Sen'e göre, başarı yaklaşımları için bu araçlar ciddi bir eksiklik barındırmaktadır yani bireylerin kapasite yeteneğini dikkate almazlar ve bu nedenle özgürlüğün kapsamını da hesaba katmazlar. Çünkü Sen'e göre teorik düzeydeki "bu yer değiştirme (kayma), özgürlüğün kapsamını yakalamak için yeterli değildir. Eğer bizim endişemiz özgürlükle ilgiliyse, o zaman elde etme gücüne sahip olduğumuz alternatif başarılar dizisi biçiminde bir özgürlük tanımı aramaktan hiçbir kaçış yoktur." (Sen, 1992:34). Eşit kaynaklar göz önüne alındığında, kaynakları önemli fırsatlara ve fiili başarılara dönüştürme kapasitelerindeki bireysel çeşitlilikler nedeniyle, iki farklı kişinin başarı özgürlüğü ile birlikte gerçek başarıları da değişebilir. Kaynakları dönüştürme kapasiteleri sadece insan çeşitliliği ile ortaya çıkmaz, aynı zamanda grup içi ve gruplar arası ilişkilerden de kaynaklanabilir. Sen bunu şu şekilde açıklamaktadır: "kaynakların sahipliğini veya birincil malların mülkiyetini eşitlemek, farklı kişilerin yararlandığı maddi özgürlüklerini eşitlemek zorunda değildir çünkü kaynakların ve birincil malların özgürlüğe dönüştürülmesinde önemli farklılıklar olabilir. Dönüşüm 
Yayla, Y. (2022). Amartya Sen: Kapasite Yaklaşımı ve Özgürlükle Kalkınma Sorunu.

Fiscaoeconomia, 6(1), 20-39. Doi: 10.25295/fsecon.1050437

sorunları, özellikle söz konusu başarılar karmaşık grup içi ilişkiler ve etkileşimlerden etkilendiğinde son derece karmaşık toplumsal sorunları da içerebilir." (Sen, 1992:33). Sen ayrıca "toplum yaşamında yer almak gibi bazı asgari toplumsal işlevleri yerine getirememeyi içeren yoksulluğun" (Sen, 1992:33) kaynakların özgürlüğe dönüştürülmesinde önemli bir sorun olduğunu vurgulamaktadır.

Üstelik Sen'e göre, Rawls'ın birincil mallar endeksi veya Dworkin'in kaynaklar üzerindeki kontrol varsayımı, bir bireyin amaçlarına ulaşmak için sahip olduğu temel özgürlüğün eksik göstergeleri olabilir. Çünkü eğer seçim özgürlüğü ile ilgileniyorsak, kişinin gerçekte sahip olduğu seçimlere bakmalıyız ve aynı sonuçların, kontrol edebildiği kaynaklara bakarak elde edileceğini varsaymamalıyız. Üstelik Rawls ve Dworkin'inki gibi çağdaş siyaset felsefesinde kaynak temelli kişilerarası karşılaştırmalar, bize özgürlüğe önem verildiği şeklinde görülebilir, ancak bu girişimler büyük ölçüde yetersizdir. Genel olarak, kaynakların ve birincil malların karşılaştırmaları, özgürlüklerin karşılaştırılması için temel oluşturamaz. Özgürlüğe gerçekten değer verildiğini göstermek ancak ince ve titiz çalışmalarla yapılabilir (Sen, 1992:38). Çünkü Sen'e göre, “Özgürlüğe ulaşmamıza yardım eden kaynaklar ile özgürlüğün kapsamı arasındaki uçurum hem teorik hem de pratikte olarak çok önemli olabilir. Özgürlük sadece başarıdan değil, aynı zamanda kaynaklar ve araçlardan başlayarak özgürlüğe kadar da tespit edilmelidir." (Sen, 1992:38).

\section{Kapasite ve İşlevler iliş̧kisi}

Sen, yukarıda da vurguladığımız gibi, bir kişinin refahını Aristotelesçi bir şekilde, kişinin hayatını yaşama biçimi ya da eylemlerini "işlevler" olarak adlandırır. Bu yaklaşımın felsefi temeli ise, Aristoteles'in Nikomakhos'a Etik'de ele aldığı, "faaliyet anlamında yaşam" yönünden "insanın iyiliği"nin kapsamlı bir incelemesini içerir. Sen'e göre, Aristoteles'in hem etik hem de politika alanında refah üzerine yoğunlaşmasının temelini 'insanın gelişmesini içeren politik ve toplumsal sonuçlarına odaklanması oluşturmaktadır (Sen, 1992:39). Sen, bir kişinin kapasitesini, kişinin "işlevlerini" seçme özgürlüğünü ya da olası alternatif yaşam biçimlerinden birini seçebilme özgürlüğünü yansıttığını ve böylece kişinin refah fırsatlarını gösterdiğini vurgulamaktadır. Sen'e göre, kapasiteler en azından iki yolla başarıya ulaşma ile ilgilidir: Her şeyden önce, kişinin yaşam biçimini seçme özgürlüğü refahı sağlamada araçsal değer taşıyabilir ve ikincisi, seçim özgürlüğünün kendisi iyi olabilir ve dolayısıyla bir kişinin refahına doğrudan katkıda bulunabilir (Sen, 1992:41).

Sen'e göre kapasite kavramının ayrıca özgürlük kavramıyla kurduğu maddi ilişki daha gerçekçidir: "Kapasite, öncelikle değerli işlevlere ulaşma özgürlüğünün bir yansımasıdır. Özgürlüğe ulaşma araçlarından ziyade doğrudan özgürlüğe odaklanır ve sahip olduğumuz gerçek alternatifleri tanımlar. Bu anlamda maddi özgürlüğün bir yansıması olarak okunabilir. İşlevler refahın kurucu unsuru olduğu sürece, kapasite bir kişinin refah elde etme özgürlüğünü temsil eder." (Sen, 1992:49).

Sen'e göre kapasite yaklaşımının gücünün önemli bir parçası da, kişileri metalar, gelirler, kamu hizmetleri vb.nin alanından yaşamın kurucu unsurlarının alanına taşımasında yatmaktadır (Sen, 1992:50). Böylece, refaha ulaşma özgürlüğü sadece kazanılan işlevlere değil aynı zamanda işlev görme yeteneğine de bağlı olmaktadır. 
Yayla, Y. (2022). Amartya Sen: Kapasite Yaklaşımı ve Özgürlükle Kalkınma Sorunu.

Fiscaoeconomia, 6(1), 20-39. Doi: 10.25295/fsecon.1050437

\section{Neden Eşitlik? Neyin Eşitliği?}

Sen, eşitlik fikrinin doğal bir adalet teorisinde mevcut olduğuna itiraz ederken, insan çeşitliliğinin eşitlik kavramında dikkate alınması gereken bir temel norm olduğunu vurgulamaktadır. Bu nedenle Sen, eşitliğin hem somut yönüne vurgu yapmakta; hem de eşitliğin değerinin hem pratik hem de ahlaki bir öneme sahip olduğunu belirtmektedir.

Sen, tüm başarılı toplumsal ve politik teorileri eşitlik kavramı çerçevesinde değerlendirir. Sen'e göre "Zamanın testine dayanan her normatif sosyal düzenleme teorisi, bir şeyin eşitliğini talep ediyor gibi görünüyor ve bu durum her teoride özellikle önemli olarak kabul edilen bir şeydir." 4 Sen'in görüşüne göre, görünüşte her yerde bulunan 'eşitlikçilik' (egalitarianism) için bir sebep vardır. Çünkü belirli bir teoride önemli olan bazı alanlarda herkes eşit olarak dikkate alınmadıkça, etik inandırııılık elde etmek zordur. Bunun mantıklı bir gereklilik olduğunu veya sadece bazılarının yaptığı gibi ahlak disiplininin bir parçası olduğunu iddia etmek çok iddialı olsa da, etik bir teorinin, herkese eşit bir şekilde bakmadan genel sosyal makullüğe nasıl sahip olabileceğini görmek zordur." (Sen, 1992:3). Sen böylece, sosyal teorilerde eşitlik kavramına yer verilmesini teorinin "etik inandırıcılığa" olan ihtiyacından kaynaklandığını vurgulamaktadır.

Kapasiteler ve koşullar gibi çok sayıda bireysel özellik nedeniyle, hangi değişkenin kişiler arasında eşit olarak dağıtılması gerektiği cevaplanması zor bir sorudur Sen'e göre. Çünkü kapsamlı bir eşitlik anlayışının bir kısmı, eşitliği değerlendirilecek en az iki çeşit çeşitliliği, insan çeşitliliğini ${ }^{5}$ ve birçok olası odak değişkenini (Sen, 1992:1) hesaba katmalıdır.

Sen'e göre, "Farklı kişiler toplumsal adalet fikrini de kapsayan etik fikirleri farklı tarzlarda yorumlayabilirler ve bu konuda kendi düşüncelerini nasıl örgütleyeceklerine dair kararsız olabilirler. Ancak temel adalet fikri, kendi çıkarları için kaygılanan, ancak aile üyelerini, komşuları, yurttaşları ve dünyadaki diğer insanları da dikkate alabilen toplumsal varlıklara yabancı değildir...Adalet ve dürüstlük fikri için insan zihninde, ahlaki bombardıman ve etik söylevleriyle yapay olarak yaratılmış bir alan yoktur. Bu alan zaten vardır ve sorun, insanların sahip oldukları genel kaygıların sistematik, ikna edici ve etkin kullanımını sağlamaktır." (Sen, 2004:354). Çünkü Sen'e göre "eşitlik özellikle güçlü ve titiz bir talep ile olabilir." Özellikle dağıtımcı adalet konusuna girildiğinde (Sen, 1992:24) "neyin eşitliği" önemli bir tartışma noktasıdır.

Ayrıca Sen'e göre, eşitliğin değerlendirilmesinde, aynı homojen alanda bile her zaman bir ölçüm problemi vardır, çünkü farklı ölçüler sıklıkla eşit derecede mantıklıdır ve temel eşitliğin hangi özelliğinin ölçüldüğüne bağlı olarak farklı sıralamalar üretir (Sen, 1992:116). Sen'e göre,

\footnotetext{
4 "Bu teoriler çeşitlidir ve çoğu zaman birbirleriyle savaşırlar. Siyasi felsefe alanındaki çağdaş uyuşmazlıklarda eşitlik, örneğin, John Rawls ('birincil malların dağıtımında eşit özgürlük ve eşitlik), Ronald Dworkin ('eşit olarak muamele ' ve ' kaynakların eşitliği '), Thomas Nagel ('ekonomik eşitlik') Thomas Scanlon ('eşitlik') ve diğerleri de genellikle 'profesyonel eşitlik' görüşüyle ilişkilendirilir." (Sen, 1992:12).

5 "Eşitlik, bir kişinin belirli bir yönünü (gelir, servet veya mutluluk, özgürlük veya özgürlük veya fırsatlar veya haklar veya ihtiyaçlar yerine getirenler gibi) başka bir kişinin aynı yönüyle karşılaştırarak değerlendirilir. Dolayısıyla, eşitsizliğin yargılanması ve ölçülmesi, karşılaştırmaların yapııdığı değişkenin (gelir, servet, mutluluk, vb.) seçimine tamamen bağıdır. Buna 'odak değişkeni' diyeceğim- yani farklı insanları karşılaştırırken analizin odaklandığı değişken." (Sen, 1992:2).
} 
Yayla, Y. (2022). Amartya Sen: Kapasite Yaklaşımı ve Özgürlükle Kalkınma Sorunu.

Fiscaoeconomia, 6(1), 20-39. Doi: 10.25295/fsecon.1050437

eşitlik fiilen insani tarafsızlık gerekliliğinin yerine getirilmesi gereken etik bir güce sahiptir. Bu nedenle özellikle "ampirik değerlendirmeler", eşitliğin dengesinin nasıl olması gerektiğinin nasıl ele alınacağı ile ilgilenmektedir. Böylece Sen biçimsel bir eşitlik kavramını kabul etmez. Dahası, eşitliğin tutarlı bir adalet kavramı olması için, karmaşık insan çeşitliliğinin gerçeğiyle bütünsel olarak ilişkili olarak ele alınması gerekir (Sen, 1992:116).

Sen'in özellikle vurguladığı gibi, eşitlik ve özgürlük çelişkili ve uzlaşmaz idealler değildirler. Bireysel özgürlüklerin ve hakların dağılımı eşitlik temelinde yapılmalıdır. Örneğin, refah eşitliğine karşı bireysel özgürlük hakkındaki görüşlere karşı çıkmak, eşitlik ve özgürlük arasındaki çatışmayı değil, uygun asli eşitliğin farklı görüşleri arasındaki çatışmayı ifade eder. Sen'in ifade ettiği gibi "problemi bu ikinci karşıtlık açısından ortaya koymak bir 'kategori hatasını' yansıtır. Eşitlik ve özgürlük birbirlerinin alternatifi değildirler. Özgürlük, eşitliğin olası uygulama alanları arasındadır ve eşitlik, özgürlüğün olası dağıtım modelleri arasındadır." (Sen, 1992:22-23).

\section{6.Özgürlükle Kalkınma}

Sen, Aristoteles'in Nikomakhos'a Etik'in en başında belirttiği cümleyi aktarır: "aramakta olduğumuz iyiliğin servet olmadığı açıktır; çünkü servet sadece faydalıdır ve başka bir şey içindir." (Sen, 1992:28). Sen'e göre, Aristoteles bir başarı kriteri olarak zenginliği yani servet ve geliri standart açıdan reddetmekte ve bu nedenle eudaimonia'yı (insani iyiliği-gelişimi) değerli faaliyetler açısından ele almaktadır ve insan eylemlerinin içinde işlediği süreçleri inceleyerek yaşamın bir parçası olarak özgürlüğün önemine işaret etmektedir (Sen, 1993:47).

Daha önce de vurgulandığımız üzere kapasite yaklaşımı bir adalet teorisi değildir (Sen, 1992:87; Wells, 1). Bununla birlikte kapasite yaklaşımının adaletle olan bağlantısı güçlüdür ve üstelik Rawıs'un çalışmasının üzerinde yükselmektedir. Bu nedenle Sen'in kapasite yaklaşımı önermesi 'etik' unsurları ekonomik süreçlere taşımaktadır. Ayrıca Nuno Martins'in de belirttiği gibi, kapasiteler ve işlevler, farklı alanların ontolojik özelliklerinin ayrıntılandırılması bağlamında eşitliği değerlendirmek için uygun alan olarak gerekçelendirilir. Burada insanın bu ontolojik analizi, biyolojik ve toplumsal alan dâhil olmak üzere farklı gerçeklik katmanlarında yapılır (bir yanda Sen'in fiziksel engelliler analizinde veya diğer yanda toplumsal dışlanma ve cinsiyet tartışmalarında olduğu gibi...). Üstelik kapasite yaklaşımının ontolojik boyutu, diğer etik teorilerle karşılaştırıldığında, bir yenilik (inovasyon) özelliği taşımaktadır (Martins, 2007:51). Bu bağlamda, Sen'in kapasite yaklaşımı ve işlevler değerlendirmesi, etik özellikleri ve yenilikçiliği ile birlikte ele alındığında özgürlükle kalkınmada farklı düşünsel ve pratik sonuçlara ulaşılmasına olanak vermektedir.

"Özgürlükle Kalkınma” kavramını öne çıkaran Sen'in amacı eşit temel insani kapasitelerinden çok daha geniş bir alanı kapsamaktadır. Sen özgürlük olarak kalkınma çalışmasında, kalkınmasını gerçekleştirmek zorunda olan toplumlar için hem bir amaç hem de bir araç olarak nasıl bir özgürlük ve eşitlik anlayışının olması gerektiğini araştırmış ve geliştirmeye çalışmıştır. Michael Quinn'e göre, Sen, bakış açısını 'özgürlüğe dayalı kapasite yaklaşımı' olarak nitelendirerek özgürlüğün merkeziyetçiliğini giderek daha fazla vurgulamıştır (Quinn, 2019:120). Sen, özgürlüğün bir kişinin hayatında oynadığı iki rol arasında ayrım yapar: kurucu rol ve enstrümantal (araçsal) rol. Özgürlüğün kurucu rolünün ekonomik kalkınmadaki rolü Sen'e göre şu şekildedir: "Özgürlüğün kurucu rolü, temel özgürlüklerin insan hayatının 
Yayla, Y. (2022). Amartya Sen: Kapasite Yaklaşımı ve Özgürlükle Kalkınma Sorunu.

Fiscaoeconomia, 6(1), 20-39. Doi: 10.25295/fsecon.1050437

zenginleştirilmesi bakımından taşıdığı önemle ilgilidir. Temel özgürlükler, açlık, beslenme yetersizliği, önlenebilir hastalıklar ve erken ölümden kaçınabilmenin yanı sıra, okuryazarlık ve hesap yapabilme, siyasal katılımdan ve serbestçe ifade imkânından yararlanma vb. özgürlüğü gibi temel kapasiteleri kapsar. Bu kurucu perspektif içinde kalkınma, bunların ve diğer temel özgürlüklerin genişletilmesini gerektirir. Bu görüşe göre kalkınma, insan özgürlüklerini genişletme sürecidir ve kalkınma değerlendirmesinin de bu düşünceyle beslenmesi gerekir." (Sen, 2004:55-56).

Sen, ayrıca "araçsal" bir yaklaşım ile beş ayrı özgürlük tipi belirler. Bu özgürlük tipleri: (1) siyasal özgürlükler, (2) iktisadi imkânlar, (3) toplumsal fırsatlar, (4) şeffaftık güvenceleri ve (5) koruyucu güvenlik'den (Sen, 2004:25) oluşmaktadır. Sen'e göre bu hak ve fırsat tiplerinin her biri bireylerin kapasitelerinin gelişmesine katkıda bulunur ve aynı zamanda özgürlüğün kurucu ve araçsal rolleri birbirini güçlendirir. Sen'e göre, kalkınmanın rakipsiz hedefi olarak insan özgürlüğünün temel hedefini, insan özgürlüğünü ilerletmek için farklı özgürlüklerin sağladığı araçsal etkinlikten ayırmak gerekmektedir. Sen, özgürlüğün araçsal rolünün, farklı türden hakların, fırsatların ve yetkilerin insan özgürlüğünün genişlemesine ve kalkınmanın ilerlemesine katkıda bulunma tarzıyla ilgili olduğunu belirtir. Bir başka ifadeyle, kalkınma çoğunlukla insan özgürlüğünü genişletme sürecinin farklı bir görünümüdür. Araçsal bağda ise bu kurucu bağlantıdan daha çoğu içerilmiştir (Sen, 2004:57). Yine Sen, kalkınmayı tanımlamak ve değerlendirmek için dikkati faydadan özgürlüğe kaydırır (Pagliari, 2011:144).

Sen'in bakış açısından bireyin özgürlüğü merkezi konumdadır. Kalkınma politikasının başarısını ölçmek için kullanılan normatif kategoriler ve varsayımların ve gelir dağılımlarını ölçmeyi öneren önlemlerin tarafsız olduğu iddialarına katılmayan ve hepsinin bazı gizli değer yargıları içerdiğini savunan Sen'e göre, GSMH'da sağlanan büyüme veya ortalama yıllık gelirde artış gibi daha geleneksel endekslere göre, birey ve özgürlükleri eşitlik ve ekonomik kalkınma endeksi olarak en iyi gösterge durumundadır (Pagliari, 2011:141). Sen, bireylerin özgürlüklerinin gelişimini makroekonomik politikalar ve ekonomik kalkınma için gerekli bir kalkış noktası olarak görüyor. Bu bağlamda özgürlükle kalkınma aynı zamanda Sen'in kapasite eşitliği olarak eşitlik anlayışını tekrar devreye sokmaktadır. Carmen Pagliari vd.'nin de ifade ettiği üzere, kapasite yaklaşımı, insanın toplumsal-ekonomik refahını, kapasite setinin genişletilmesine ve insanların kendi yaşam tarzlarına ulaşma özgürlüğüne bağlar ve ekonomik zenginliği bir amaç olarak değil, kapasite setini genişletme araçlarından yalnızca biri olarak görür (Pagliari, 2011:140).

Sen, bireysel kapasite geliştirme ve yetkilendirme hakkındaki düşüncelerini işsizliğin yarattığı bazı sorunları gidermek için çözüm olarak getirilen işsizlik fonuna karşı bireylere iş yaratmanın zorunluluğuna ilişkin düşüncelerinde ortaya koymaktadır. Sen, çalışanlardan işsizlere zorunlu gelir transferleri yoluyla yüksek işsizlik ödeneği sağlanmasının işsiz olmanın olumsuz sonuçlarını etkisiz hale getirebileceği varsayımını reddeder. Sen, bunun bir yanılgı olduğunu savunmaktadır, çünkü işsizliğin, işsizlik yardımları sağlayarak düzeltilemeyecek birçok dezavantajı vardır. Bu bağlamda Sen, işsizliğin olumsuz sonuçlarını sıralar (Sen, 1997:161): Mevcut üretim kaybı ve mali yük; özgürlük kaybı ve sosyal dışlanma; beceri kaybı ve uzun vadeli maliyet; psikolojik zarar; hastalık ve ölüm; motivasyon kaybı; insan ilişkileri ve aile hayatı eksikliği; ırk ve cinsiyet eşitsizliği; toplumsal değer ve sorumluluk kaybı; örgütsel katılık ve vasıflı yaşlı işçinin kaybı. Bu çerçevede aynı zamanda Sen'in kapasite yaklaşımının, insan 
Yayla, Y. (2022). Amartya Sen: Kapasite Yaklaşımı ve Özgürlükle Kalkınma Sorunu.

Fiscaoeconomia, 6(1), 20-39. Doi: 10.25295/fsecon.1050437

\begin{abstract}
çabalarının amacının, arzu süreçlerinin ve pratik mantığının çok daha karmaşık olması nedeniyle kişisel çıkarları en üst düzeye çıkaran, ilişkilerden, duygulardan veya farklı bağ|ılıklardan kurtulmak için hareket eden 'rasyonel iktisadi insan' düşüncesinden bir kopuş (Sen, 1977; Hahnel, 2002:68; Çakmak, 2008) olduğu belirtilmelidir. Böylece Sen, yalnızca bireysel tercihlerin tatmininin davranış normlarına yön vermesi gerektiği şeklindeki genel varsayıma da itiraz etmektedir. Sen, bunun yerine, insanların temel kapasitelere sahip olması durumunda toplumsal faktörlerin de bu konuda rol oynaması gerektiğini ifade etmektedir.
\end{abstract}

Refah kavramı, Sen'in özgürlük kavramını anlamasının merkezinde yer almaktadır. Aslında, refah onun için özgürlüğün olmazsa olmazıdır ve refah özgürlük için somut bir temel oluşturur. Bir dereceye kadar refah "bir kişinin varlığının kalitesi ya da iyiliğidir". Sen'e göre, refah, aktivite kavramını dönüştüren "wellness" (zindelik, sağlıklılık) ile ilgilidir. O halde refah bir anlamda etkinliği/eylemi içerir ve sadece kamu hizmeti veya birincil mallara statik olarak sahip olmak meselesi değildir (Sen, 1992:39). Ayrıca, Sen'in tanımı, faaliyet kavramını kişi kavramıyla ilişkilendirir. Sen için birey eylemleri ile yani "yapıyor" olmakla bir varlık haline gelir. Fakat Sen metafizik bir yaklaşımı reddeder. Yine de, varlık kavramını kullanması, insanlarda var olan insanın doğasının olduğunu kabul eder. Dahası, Sen'e göre, refaha sahip olmak, onun dışında bir şey değil, onda başardığı bir şeydir dolayısıyla eylemle bütünleşmiştir (Sen, 1985:195).

Fakat Sen'e göre bu, refahın genel bir özelliğidir. Bu nedenle Sen, "değişen kişisel özellikler" (Sen, 1999:6-7) olarak adlandırdığı şeye karşılık gelen bir refah özgürlüğü kavramı geliştirir. Sen'e göre "Özgürce hareket etmek ve seçim yapabilmek sadece daha fazla özgürlüğün daha fazla alternatifi mümkün kıldığı için değil, doğrudan refaha etki ettiği için" zorunludur. Ayrıca özgürlük genel olarak "değer verdiğimiz şeyi başarmak için gerçek fırsat"dır. Sen'e göre, "Fırsat" ve "sorumluluk" arasındaki ayrım çok önemlidir. Fırsat, "kendi kendine yapılabilen" seçimlerle ilgili iken; sorumluluk, "kendi kendine yapılması gereken seçimler"dir (Sen, 1992:63). Refah özgürlüğü, sorumluluklarla yaşamaktan fırsatları dikkate alarak yaşamak olarak değerlendirilmektedir çünkü fırsat, yaşamın en temel yönlerine katılmayı seçme yeteneği olarak anlaşılmaktadır. Sen'e göre fırsatlar karşısında bireyin yapacağı seçimler, refahın bireylere sunacağı değerler dikkate alınarak yapılmalıdır. Örneğin, Sen "uzun yaşamak"ın bir işlev olduğunu yani tüm insanlar tarafından değer verilen bir etkinlik olduğunu söylemektedir. Üstelik Sen'e göre uzun yaşamakta özgürlüğe bağlıdır. Sen'in ifadesiyle "daha uzun yaşama fırsatı genellikle her birey tarafından arzulanır." (Sen, 1988:280). Böylece Sen, refah özgürlüğünü, temel insan işlevlerinin arzusu ve değerlemesi çerçevesinde yapılan insancıllaştırıcı bir faaliyet olarak görmektedir (Çiğdem, 2012:86).

Yoksulluk ve kapasite ilişkisini de ele alan Sen'e göre yoksulluk, yalnızca kişinin düşük bir gelire sahip olduğu anlamına gelmemektedir, aynı zamanda kapasitesini kullanamayacağı anlamına da gelebilmektedir. Aslında, bazı kişiler, diğerlerini yoksulluğa sürükleyecek bir gelir düzeyinde iyi işlev görebilir. Örneğin hamilelik, çalışma yeteneği veya evdeki roller gibi faktörler, kadınların temel bir kapasiteyi işleve dönüştürmesini erkeklerden daha zor hale getirebilir. Bir kapasiteyi bir işleve "dönüştürebilmek", tamamen gelire dayalı bir yoksulluk tanımının ele almadığı bir konudur. Sen'e göre “Gelirin temel yeteneklere dönüştürülmesi, bireyler arasında ve aynı zamanda farklı toplumlar arasında büyük farklılıklar gösterebilir, böylece asgari düzeyde kabul edilebilir temel kapasiteler düzeylerine ulaşma yeteneği, minimum düzeyde yeterli gelir seviyeleri ile karşılanabilir. Yoksulluğun gelir merkezli görüşü, yani kişilerarası 
Yayla, Y. (2022). Amartya Sen: Kapasite Yaklaşımı ve Özgürlükle Kalkınma Sorunu.

Fiscaoeconomia, 6(1), 20-39. Doi: 10.25295/fsecon.1050437

değişmez bir 'yoksulluk sınırı'nı oluşturan gelirin belirlenmesi, yoksulluğun belirlenmesi ve değerlendirilmesinde çok yanıltıcı olabilir." (Sen, 1993:50).

Amartya Sen'e göre yoksulluk, öncelikle bir kapasite eksikliğidir (Sen, 1983; Çiğdem, 2012:88; Metin, 2014; Yurdakul, 2010). Parası olmayan kimse yiyecek, giyecek, yakıt veya barınak gibi malları satın alamaz. İnsanların intiyaç duydukları şeyler veya "metalar", farklı toplumsal bağlamlarda farklı şekilde anlaşılır, ancak asıl sorun, insanların yemek, yaşamak, dolaşmak vb. gibi yapmaları gereken şeyleri yapıp yapamayacaklarıdır. Çoğu zaman yoksul insanlar kaynaklarını kontrol etmek zorunda kalırlar ve yoksunluk örüntüsü sürekli değişir. Yoksul insanlar bazen giyecek almaya aç bir halde gidebildikleri gibi bazen de çocuklarını okula göndermek için giyecek almaktan vazgeçebilirler. Sen'in kapasite eksikliğinin giderilememesinin yarattığı yeniden yeniden yoksulluğun üretilmesine ekonomik kalkınma literatüründe Nurkse'nin azgelişmişliğin kısır döngüsü kavramına benzer şekilde 'yoksulluğun kısır döngüsü' veya 'yoksulluk ağı' denebilir.

Sen'e göre, yoksullukla bağlantılı kapasitelerin eksikliği, insanların maddi olarak ne yapıp ne yapamayacakları sorunu değildir. Bu durum yetki eksikliğinden kaynaklanmaktadır. Örneğin yoksulların yoksunluğu, yeterli gıdanın olmamasından değil, insanların üretilen gıda mallarına sahip olma hakkına sahip olmadığı yerlerde ortaya çıkmaktadır. Yiyecek satın alamayan kişi, diğer insanların sahip olduğu seçeneklere sahip değildir ve bu yüzden özgür değildir. Ama yoksulluk, gıda gibi tek bir mala özgü olmayan genel bir durumdur. Yiyecek alma hakkının olmaması, genellikle modern toplumda parasızlıktan kaynaklanan daha genel bir hak eksikliğinin göstergesidir. Sen, özgürlüğün ekonomik ve toplumsal kalkınma yoluyla genişletilmesini savunmaktadır. Ekonomik kalkınma sadece mal ve hizmetler arzını arttırdığı için değil, aynı zamanda temel hakları geliştirdiği için de önemlidir. İnsanlar uygulanan ekonomiye uyum göstererek haklar kazanırlar. Ancak bu haklar politik süreçler ile de geliştirilebilir. Ayrıca, Sen, demokraside hiçbir zaman bir kıtlık olmadığını savunmaktadır (Sen, 2004:31).

Sen'e göre, bir kişinin farklı değerli işlevleri yerine getirme kapasitesi, kamusal eylem ve politika ile büyük ölçüde artırılabilir ve bu kapasite genişlemeleri özgürlük için çok önemlidir (Kirmanoğlu, 2005:28). Çünkü örneğin, hükümetin sıtmaya karşı önlem alması, eğitim alma olanağı tanıması veya işgücü piyasasında eşit fırsatlar sağlaması bireylere yaşam tarzlarını seçme özgürlüğünü verecektir (Sen, 1993:54). Diğer bir ifadeyle kapasiteler yaklaşımının özü, ekonomik ve siyasal karar alıcılara, kaliteli bir insan yaşamının ve yoksulluk ve yoksunluğun ne olduğuna dair yanlış düşüncelerini göstermek ve yoksulluğu yeniden üretecek yani yoksulluk ağını kıracak önlemleri göstermesidir.

Sen'in savunduğu insan özgürlüğünün genişlemesi ve kapasite yaklaşımı sayesinde, dünya işbölümünün ve ulusal pazarların küresel bağlantısının sosyal bir olumlu sonuç üretebileceğini de varsaymak mümkündür (Pagliari, 2011:139). Fakat bunun gerçekleşmesi için Sen, gelişmiş ülkelerin gelişmekte olan ülkelere nasıl kalkınacakları konusunda reçeteler vermesinden veya hükümetlerin yoksul vatandaşlarına refah yardımı sağlamasından daha çok, gelişmekte olan ülkelerin kaynaklarını ve vatandaşlarının kapasitelerini geliştirmelerine yardımcı olmalarını önermiştir. Sen, başarılı bir ekonomik sistemin insanların yaşamsal işlevleri yerine getirmek için ihtiyaç duydukları kapasiteleri sağlaması olduğunu belirtir. Bu "işlevler" beslenmek ve korunmak, temiz hava solumak gibi temel fiziksel şeyleri ve kendine saygı, topluluk yaşamına 
Yayla, Y. (2022). Amartya Sen: Kapasite Yaklaşımı ve Özgürlükle Kalkınma Sorunu.

Fiscaoeconomia, 6(1), 20-39. Doi: 10.25295/fsecon.1050437

katılma ve var olma gibi daha soyut kavramları da içerebilirler. Daha önce de değindiğimiz gibi Sen'e göre iktisadi özgürlüğün olmamasının uluslara sağlayacağı tek şey acıdır hatta ölümdür. Belirtilmelidir ki Sen'e göre “iktisadi özgürlük yoksunluğu sosyal özgürlük yoksunluğunu doğurabildiği gibi, sosyal ya da siyasal özgürlük yoksunluğu da iktisadi özgürlük yoksunluğunu besleyebilir." (Sen, 2004:23). Bu nedenle "önlenmesi mümkünken kıtlıklara izin veren bir toplum belirgin biçimde adaletsizdir, ancak bu teşhisi, ülkede yaşayan bütün insanlar arasında benzersiz bir gıda, gelir ya da yetki paylaşım modelinin azami ölçüde adil olacağına ve bunu başka paylaşımların (tamamen birbirine göre düzenlenmiş) izleyeceğine dair bir inanca dayandırmak zorunlu değildir. Adalet fikirlerinin konuyla ilişkisi, dünyanın nasıl yönetilmesi gerektiğine dair günümüze kadar gelen bazı formüllerin türetilmesinden çok, üzerinde makul bir anlaşmanın mümkün olduğu aşikâr adaletsizliğin saptanmasında yatar." (Sen, 2004:387).

\section{Sonuç}

Liberal gelenekteki adalet teorilerini, gerçek insan yaşamına odaklanmamak ve gerçekten eşitlikçi olmamakla eleştiren Amartya Sen'in iktisadi adalet, refah, kalkınma ve özgürlükler üzerine düşüncesinin özünü, kapasite yaklaşımını temel alarak özgürlüklerin kullanım alanlarının toplumda yaygınlaştııımasının ekonomik-toplumsal kalkınmanın hem amacı ve hem de aracı olması oluşturmaktadır. Çünkü Sen'e göre, özgürlük ve toplumsal refah, sadece ulaşılması gereken amaçlar değildir, aynı zamanda refahı ve kalkınmayı da teşvik eden araçlar konumundadırlar. Bu bağlamda Sen'e göre, özgürlük kavramı kamusal ve özel alan ayrımına tabi olmadığı gibi sadece ekonomik özel alana ait bir kavram da değildir; özgürlük nosyonu ekonomik-toplumsal bütün canlıların yaşamına ait bir kavramdır. Son olarak denebilir ki, Amartya Sen'in önem verdiği işlevsellik ve yapabilirlik kavramları hakkaniyetli ve demokratik bir toplumun yaratılmasında hem kamu politikalarının oluşturulmasında hem de piyasanın şekillenmesinde özellikle politika yapıcılarına Prometheus'un ateşini sunabilir.

\section{Kaynakça}

Alexander, M. John. (2016). Capabilities and social justice the political philosophy of Amartya Sen and Martha Nussbuam, Routledge, Taylor \& Francis Group.

Boz, Çiğdem. (2012). Adam Smith ve Amartya Sen, Gazi Üniversitesi Iktisadi ve Idari Bilimler Fakültesi Dergisi 14/3.

Çakmak, Hatice Karaçay. (2008). Sen'in Yetenek Yaklaşımı Anaakım Iktisada Alternatif Bir Paradigma Sunmakta Mıdır?, Ekonomik Yaklaşım, Cilt : 19, Sayı : 68.

Daniels, Norman (ed). (1989). Reading Rawls: Critical Studies on Rawls' A Theory of JusticeStanford University Press.

Daniels, Norman. (1989). Equal Liberty and Unequal Worth of Liberty, içinde Daniels, Norman (ed), (1989). Reading Rawls: Critical Studies on Rawls' A Theory of Justice, Stanford University Press.

Gilardone, Muriel. (2015). Rawls's influence and counter-influence on Sen: post-welfarism and impartiality. European Journal of the History of Economic Thought, Taylor \& Francis (Routledge), 2015, 22 (2). 
Yayla, Y. (2022). Amartya Sen: Kapasite Yaklaşımı ve Özgürlükle Kalkınma Sorunu.

Fiscaoeconomia, 6(1), 20-39. Doi: 10.25295/fsecon.1050437

Hahnel, Robin. (2002). AMARTYA SEN: The Late Twentieth Century's Greatest Political Economist? içinde Douglas Dowd (edit), Understanding Capitalism: Critical Analysis from Karl Marx to Amartya Sen, Pluto Press, London.

Kirmanoğlu, Hülya. (2005). Amartya Sen'in Özgürlük Ve Kalkınma Üzerine Düşüncelerine Bir Bakış. İstanbul Üniversitesi Iktisat Fakültesi Maliye Araştırma Merkezi Konferansları, 47. Seri.

Martins, Nuno. (2007). Ethics, Ontology and Capabilities. Review of Political Economy, 19:1.

Metin, Banu. (2014). Yoksullukla Mücadeleye İnsan Hakları Açısından Bakmak: Amartya Sen'in Kapasite (Capability) Yaklaşımı Temelinde Bir Değerlendirme. Journal of Yasar University, 2014 9(36).

Garnham, Nicholas. (1997). Amartya Sen's 'Capabilities' Approach to the Evaluation of Welfare: Its Application to Communications. Javnost - The Public, 4:4.

Nussbaum, Martha and Sen, Amartya (edit). (1993). The Quality of Life, Wider Studies in Development Economics, Oxford University Press, USA.

Pagliari, Carmen, Bucciarelli, Edgardo and Michele Alessi. (2011). From Adam Smith to Amartya Sen: global market as a possible instrument to promote socio-economic development. Investigación Económica , octubre-diciembre de 2011, Vol. 70, No. 278.

Quinn, Michael. (2019). 'The First Article to Look to is Power': Bentham, Happiness and the Capability Approach. içinde Georgios Varouxakis and Mark Philp (edit), Happiness and Utility, UCL Press, London.

Rawls, John. (2005). A Theory of Justice Original Edition, The Belknap Press, England.

Rawls, John. (2019). Siyasal Liberalizm, çev. Mehmet F. Bilgin, Bilgi Üniversitesi Yay., İstanbul.

Rawls, John. (2020). Hakkaniyet Olarak Adalet, çev. Osman Baş, Pinhan Yayınları, İstanbul.

Sen, Amartya. (1995). Well-Being, Agency, and Freedom. The Journal of Philosophy, Apr., 1985, Vol. 82, No. 4.

Sen, Amartya. (1977). Rational fools: A critique of the behavioural foundations of economic theory. Philosophy and Public Affairs, vol. 6.

Sen, Amartya. (1983). Poor, relatively speaking, Oxford Economic Papers, vol 35, no 2.

Sen, Amartya. (1988). Freedom of Choice: Concept and Content. European Economic Review Volume 32, Issues 2-3, March 1988.

Sen, Amartya. (1990). Justice: Means Versus Freedoms. Philosophy and Public Affairs Vol. 19, No.2 (Spring 1990)

Sen, Amartya. (1993). Capability and Well-Being. içinde Nussbaum, Martha and Sen, Amartya (edit), 1993, The Quality of Life, Wider Studies in Development Economics, Oxford University Press, USA.

Sen, Amartya. (1997). Inequality, Unemployment and Contemporary Europe. International Labour Review, Vol. 136, No. 2, Summer 1997. 


\section{Sen, Amartya. (1999). Commodities and Capabilities, Oxford Press, UK.}

Sen, Amartya. (2004). Özgürlükle Kalkınma, çev. Yavuz Alogan, Ayrıntı Yayınları, İstanbul.

Sen, Amartya. (2009). Equality of Capacity. https://philpapers.org/rec/SENEOC

Sen, Kumar Amartya. (1979). Equality of What. The Tanner Lectures on Human Values.

Sen, Kumar Amartya. (1992). Inequality Reexamined, Clarendon Press, Oxford.

Wells, Thomas. Sen's Capability Approach as an organising framework for open evaluation. www.google.com

Yurdakul, Funda. (2010). Amartya Sen'in Yoksulluk Üzerine Düşünceleri ve Sen Yoksulluk Indeksi: Türkiye Uygulaması. E-Journal of New World Sciences Academy, Vol:5(Number:3).

Etik Beyanı: Bu çalışmanın tüm hazırlanma süreçlerinde etik kurallara uyulduğunu yazar beyan eder. Aksi bir durumun tespiti halinde Fiscaoeconomia Dergisinin hiçbir sorumluluğu olmayıp, tüm sorumluluk çalışmanın yazarına aittir.

Ethics Statement: The author declares that ethical rules are followed in all preparation processes of this study. In case of detection of a contrary situation, Fiscaoeconomia has no responsibility and all responsibility belongs to the author of the study. 
Yayla, Y. (2022). Amartya Sen: Kapasite Yaklaşımı ve Özgürlükle Kalkınma Sorunu.

Fiscaoeconomia, 6(1), 20-39. Doi: 10.25295/fsecon.1050437

\section{Amartya Sen: The Capacity Approach and the Problem of Freedom and Development}

\section{Yavuz YAYLA}

\section{Extended Abstract}

Amartya Sen prioritizes the diversity of people's individual capacities in determining distributive justice. Sen also criticizes John Rawls' theory of justice and other justice theories within this framework. According to Sen, the theory of justice should be considered within the framework of a person's basic capacities. The thinker developed the concept of 'basic capacity' in this basic context while addressing the question of 'equality of what?' and he first put forward the capacity theory by evaluating the strengths and shortcomings of Rawls' theory of justice as fairness.

Sen states that the concept of 'equality' in economic and normative terms should be evaluated as "individual advantage to the freedom to obtain and to combine real achievements to carry this freedom forward".

Sen critically approaches the indexical primacy established by Rawls between the liberty principle and other advantages, and asks the question of how, in such a precedence relationship between liberties and other advantages, an economic need that can be a matter of life and death can count as a lower status than personal liberty. Sen criticizes Rawls's claim that freedom, which includes basic political and civil rights, is superior to other rights, and argues that it is not sufficient to consider freedom only as an advantage that a person obtains, such as an extra income unit, and therefore the concept of primary values is an inadequate theory asserts. Sen finds Rawls' idea of freedom flawed. For Sen, giving priority to primary values, as Rawls does, leads to a partially blind morality. Sen also describes Rawls' approach to equality regarding primary values as "fetishist". According to Sen, Rawls considers primary values (liberty) as the embodiment of interest rather than a relationship between goods and people, and in this way considers primary values as the embodiment of advantage instead of using it as a relationship between people and goods. is to fall into the trap of what Marx calls 'commodity fetishism'. According to Sen, who emphasizes that primary values are turned into a fetish, the foundations of normative evaluation are; There should be neither means of freedom (such as primary values, resources, or incomes) nor mental states (such as happiness and satisfaction). The most appropriate point of view is capacities and functionalities. In other words, Sen denies that Rawls' concept of primary goods includes or presupposes a comprehensive understanding of the good.

According to Sen, a theory of equity should combine Rawls' primary goods approach with welfarist notions of equality, that is, it should reflect levels of satisfaction in meeting individual needs. For Sen, while the focus on basic capacities may be seen as a natural extension of Rawls' view of primary goods, it shifts attention away from goods to what goods do to people. "In contrast to this approach of basic capacity, Rawls' approach focuses, for example, on income rather than what income does, on self-esteem itself rather than on the 'social foundations of self-respect'."

According to Sen, considering the diversity assumption, it is possible to see great diversity in how people can transform or effectively use primary goods when choosing a preferred way of life. Sen argued that the equality of primary goods may coexist with serious inequalities in 
Yayla, Y. (2022). Amartya Sen: Kapasite Yaklaşımı ve Özgürlükle Kalkınma Sorunu.

Fiscaoeconomia, 6(1), 20-39. Doi: 10.25295/fsecon.1050437

practical life and this situation may be covered up. For example, according to him, a person with a disability may own more primary goods, such as a higher income, but may be less likely to lead the kind of life he wants than those with a lower income. Moreover, the practical manifestation of poverty is often not conveyed by a single quantity of primary goods. In this context, it is also necessary to pay attention to human diversity, such as age, disability and disease propensity, in order to transform primary goods into real choices for purposes. In other words, when we consider the diversity of people, it should be noted that people's goals are different from each other and therefore their needs also differ. Therefore, in order to achieve the same goals, a person in a more disadvantaged situation, such as a physically disabled person, needs different resources than a healthy individual. Therefore, to determine equality, it is not sufficient to focus solely on primary goods, whether because of the primary good of freedom or otherwise. On the contrary, Sen says that equality can only be determined in terms of the relationship between goods and persons.

Sen's "Equality of What?" in his work; He developed the concept of "capacity" by criticizing the approaches of utilitarianism and Ralws's idea of justice to equality. The capacity approach is an approach that focuses on what people can really do or be, as opposed to welfarist (utilitarian) and resource-based approaches to normative assessments. The main claim of the capacity approach is; In order to understand how well a person is, it is necessary to look at what kind of life the person leads and what he has achieved in terms of existence and actions. Thus, the capacity approach can be defined as a broad normative framework for the evaluation of individual well-being and social arrangements, and for the design of proposals and policies for changes in society.

In other words, Sen's capacity approach focuses on the scope of freedom to achieve goals rather than just having the means to freedom. In this context, too, functions that a person achieves at any given time (for example, learning Chinese, being a good gourmet, being able to swim, being able to love someone, etc.) are certain existence, actions, or things he enjoys. As Nicholas Garnham points out, the capacities approach allows us to take a much more nuanced approach to the problem and to distinguish between different potential uses of the subject (e.g. the media) and actual uses, and ask why existing potentials are not being realized.

Functions, which are a framework concept for resources, activities and attitudes that people regard as intrinsically important, also reflect the well-being of individuals, according to Sen: "How well a person is, what kind of life he or she leads, and what the person 'does' or 'does'. reflects well-being to the extent that it shows the truth about what he has achieved." Sen also states that functions are the elements that make up a person's being, and they are characteristics of both his actions and a person's states of being. Functions in this context range from "basic functions such as adequate nutrition and avoidance of preventable diseases to very complex activities or personal situations such as being able to participate in community life and having a sense of self-esteem".

According to Sen, the importance of resources is derivative. According to Sen, "The derivative significance of primary goods or resources depends on the relevant opportunities to convert primary goods or resources to the achievement of relevant objectives or the freedom to pursue them." Thus, functionalities are judged by purpose, and the size of an individual's set of capacities, or the extent of his freedom, is determined by the totality of the relative values 
Yayla, Y. (2022). Amartya Sen: Kapasite Yaklaşımı ve Özgürlükle Kalkınma Sorunu. Fiscaoeconomia, 6(1), 20-39. Doi: 10.25295/fsecon.1050437

of the functions. Sen's individuals value functions because they have the capacity to turn them into goal achievements.

Emphasizing the concept of "Development with Freedom", Sen's aim covers a much wider area than equal basic human capacities. In his development work as freedom, Sen has researched and tried to develop what kind of an understanding of freedom and equality should be for societies that have to realize their development, both as an end and a tool. Thanks to the expansion of human freedom and the capacity approach advocated by Sen, it is also possible to assume that the world division of labor and the global interconnection of national markets can produce a social positive outcome. 